\title{
IMPLIKASI PERSEPSI HAK KEPEMILIKAN TERHADAP TINDAKAN MASYARAKAT DALAM PENGELOLAAN SUMBERDAYA PERIKANAN LAUT (STUDI KASUS DI DESA TELUK, KABUPATEN PANDEGLANG, PROPINSI BANTEN)
}

\author{
Fatriyandi Nur Priyatna, Tjahjo Tri Hartono dan Zahri Nasution")
}

\begin{abstract}
ABSTRAK
Penelitian ini bertujuan untuk mengkaji persepsi hak kepemilikan, dasar pengambilan keputusan dalam bertindak dan implikasinya terhadap model pengelolaan sumberdaya perikanan (SDP). Metode penelitian yang dipilih adalah metode triangulasi, yaitu gabungan dari studi kasus, observasi dan studi pustaka. Penelitian dilakukan di Desa Teluk, Kabupaten Pandeglang, Propinsi Banten selama Bulan April-Juni 2004. Data primer yang dikumpulkan terkait dengan persepsi hak kepemilikan, konservasi dan indigenous knowledge masyarakat setempat. Pemilihan informan dilakukan dengan teknik snowballing sampling dengan jumlah informan kunci sebanyak empat orang dan informan tambahan sebanyak delapan orang. Analisis data dilakukan secara deskriptif yang didasarkan pada teori rational choice dan konsep prisoner's dilemma. Hasil analisis data menunjukkan persepsi masyarakat sangat berpengaruh terhadap dasar pengambilan keputusan dalam bertindak dan memiliki implikasi terhadap model pengelolaan SDP. Masyarakat tidak mengenal sistem hak kepemilikan SDP. Hal ini berdasarkan persepsi bahwa semua orang berhak memanfaatkan SDP karena laut merupakan milik Allah. Masyarakat juga merasa tidak berkewajiban melakukan upaya konservasi karena anggapan "ikan tidak akan habis" dan pertimbangan rasional jangka pendek untuk kepentingan ekonomi. Hasil penelitian menyebutkan bahwa konsepsi non-property right system berimplikasi terhadap pengelolaan SDP secara open access.
\end{abstract}

ABSTRACT: Implication of community perception on the property rights to the management practiced of marine fishery resource (Case study at the Teluk Village, Pandeglang district, Province of Banten). By: Fatriyandi Nur Priyatna, Tjahjo Tri Hartono and Zahri Nasution

The objectives of this research was to assess property right perception as a base for decision making in people action and those implications to the fisheries resource management. This research applied triangulation methods (case study, observation and literature study) using primary and secondary data. The research was conducted during April to June 2004 at the Teluk Village, Pandeglang Sub-Province, Banten. Primary data collection mostly related to property right and conservation perception, and also indigenous knowledge which used snowballing technique. Primary data collected from four key-person informants and eight verified informants. Data analysis used descriptive technique and also used rational choice theory and prisoner's dilemma approach. The results indicated that people perceptions highly influenced as a base for decision making in people action for fisheries resource management practiced. Community had no property right system because of open access of resource exploitation perception due to resource-ownership by Allah (God). Community also believed that there is no compulsary obligation for conservation because of "unlimited fish population" perception and economic shortterm self interest. The results also showed that non-property right system generated open access system at the present time on management practised of marine fishery resources.

KEYWORDS: perception, property right system, rational choice, prisoner's dilemma

\section{PENDAHULUAN}

Kondisi sumberdaya perikanan yang bersifat milik bersama (common property), memiliki konsekuensi terhadap akses bagi pengelolaannya. Konsekuensi akses pengelolaan tersebut dapat bersifat eksklusif bagi kelompok tertentu atau seringkali bersifat open access. Permasalahan yang kemudian muncul akibat pengelolaan yang bersifat open access adalah tidak adanya pihak yang bertanggungjawab dalam pemeliharaan kelestarian sumberdaya. Hal ini kemudian mendorong terjadinya kondisi "tragedy of

Peneliti pada Balai Besar Riset Sosial Ekonomi Kelautan dan Perikanan 
the common" (Hardin, 1968). Terkait hal ini, BendaBeckmann et al. (2001) berpendapat bahwa, kebebasan berpindah tempat mencari sumberdaya baru merupakan salah satu alasan tidak adanya pihak yang peduli untuk mengembalikan sumberdaya perikanan yang telah rusak atau habis. Hal lainnya adalah karena konservasi dianggap hanya akan menghambat usaha, menambah biaya produksi dan akhirnya mengurangi keuntungan (Kinseng, 2003).

Perilaku dan tindakan manusia dalam pengelolaan sumberdaya tidak terlepas dari persepsi hak kepemilikan suatu sumberdaya yang dimiliki oleh masing-masing pelaku usaha. Persepsi merupakan salah satu unsur dari bentuk kebudayaan yang bersifat abstrak dan berada dalam alam pikiran setiap manusia (Koentjaranigrat, 1990). Bakker (1984) menjelaskan bahwa manusia di dalam kebudayaannya mengakui alam dalam arti seluas-luasnya sebagai ruang pelengkap untuk semakin memanusiakan dirinya, yang identik dengan kebudayaan alam. Manusia tidak menguasai alam, namun mengetahuinya. Aspek formal kebudayaan terletak dalam karya budi yang mentranformasikan data, fakta, situasi dan kejadian alam yang dihadapinya menjadi sebuah nilai bagi manusia. Hal ini berarti bahwa kebudayaan merupakan hasil dari kemajuan terhadap data dan fakta alam. Lebih lanjut disebutkan bahwa tujuan dari kebudayaan itu sendiri adalah upaya mencapai kemuliaan manusia dan memuliakan alam (Bakker, 1984).

Berdasarkan uraian tersebut di atas maka dapat disimpulkan bahwa persepsi dalam hal ini dianggap sebagai suatu proses masyarakat mengetahui beberapa hal dengan menggunakan panca inderanya terkait dengan pengelolaan dan pemanfaatan SDP secara lestari. Dalam tahapan proses selanjutnya, persepsi dapat menjadi suatu konsepsi. Hal ini terjadi pada saat persepsi yang dimiliki menjadi bahan pemikiran (individu atau masyarakat) untuk membuat suatu rancangan tindakan (Susanto, 1984; Koentjaraningrat, 1990; Poerwanto, 2000; Berry, 2003; Nasution et al., 2004).

Teori rational choice menyebutkan bahwa perilaku manusia dalam menghadapi sumberdaya bersifat commons, seperti sumberdaya perikanan, cenderung short-term self interest dan hanya memaksimalkan keuntungan atau kepuasan (utility) sesaat. Persepsi ini kemudian menimbulkan sikap free rider bagi sebagian besar pelaku dalam tindakan ekonomi (Bromley, 1992). Sikap free rider dapat diartikan bahwa pelaku hanya ingin mendapatkan keuntungan tetapi enggan turut serta di dalam usaha-usaha untuk mendatangkan keuntungan tersebut. Sebagai contoh sikap free rider dalam pengelolaan dan pemanfaatan sumberdaya adalah sikap yang hanya ingin memanfaatkan sumberdaya, namun enggan terlibat dalam upaya-upaya menjaga kelestarian sumberdaya tersebut.

Beranjak dari pengertian rights atau property rights (hak kepemilikan), maka seperti yang disebutkan Bromley (1991) property rights seharusnya dimaknai lebih dari hanya sekedar hubungan antara pemilik dengan sumberdaya, tetapi juga antara pemilik dengan orang lain yang memiliki kepentingan atas sumberdaya yang sama. Lebih lanjut disebutkan bahwa, sebenarnya para ahli telah menyadari pengelolaan sumberdaya yang didasarkan atas faktorfaktor fisik dan sosial budaya dipandang mampu untuk meningkatkan responsibility dan peran serta di dalam menjaga kelestarian lingkungan hidup.

Berdasarkan hal tersebut di atas, maka kajian terkait dengan persepsi masyarakat terhadap konsep hak kepemilikan sumberdaya perikanan perlu dilakukan. Hal ini didasarkan atas premis persepsi konsep hak kepemilikan sumberdaya perikanan akan berpengaruh terhadap tindakan masyarakat dalam pengelolaan sumberdaya perikanan.

Propinsi Banten merupakan sebuah Propinsi baru yang memiliki potensi sumberdaya laut. Basis perikanan laut di daerah ini terpusat pada Kabupaten Serang dan Pandeglang. Selain itu, masyarakat nelayan yang berasal dari daerah Banten juga banyak menetap dan tersebar di beberapa daerah pesisir lainnya. Kemudian, mengingat persepsi merupakan suatu hal yang terikat dengan norma dan budaya yang terinternalisasi bagi anggota masyarakatnya akan terbawa dalam tingkah lakunya (Koentjaraningrat, 1990). Berdasarkan hal tersebut, maka dirasakan perlu untuk melakukan studi kasus di lokasi Desa Teluk, Kecamatan Labuan, Kabupaten Pandeglang, Propinsi Banten. Secara spesifik, penelitian ini bertujuan untuk mengidentifikasi persepsi hak kepemilikan, dasar pengambilan keputusan dalam bertindak dan implikasinya terhadap pengelolaan sumberdaya perikanan laut. Penelitian ini diharapkan juga dapat memberikan gambaran keadaan masyarakat nelayan di daerah lainnya yang memiliki struktur komunitas yang sama.

\section{METODE}

\section{Metode Penelitian}

Penelitian ini menggunakan metode penelitian yang bersifat kualitatif yaitu triangulasi. Proses kerja dari metode triangulasi melibatkan kombinasi sumber data, tenaga peneliti, teori dan metodologi dalam suatu penelitian tentang suatu gejala sosial (Denzin, 1970 
dalam Sitorus, 1998; Babbie, 1991). Metode triangulasi dalam penelitian ini menggunakan gabungan dari studi kasus, observasi dan studi pustaka. Metode penelitian yang bersifat triangulasi diharapkan mampu untuk menutupi kekurangankekurangan dalam penelitian sehingga tangkapan atas realitas sosial menjadi lebih valid.

\section{Penetapan Lokasi dan Unit Analisis Penelitian}

Penelitian ini dilakukan di Desa Teluk, Kecamatan Labuan, Kabupaten Pandeglang, Propinsi Banten. Penelitian dan pegambilan data dilakukan selama April-Juni 2004. Desa Teluk dipilih sebagai lokasi penelitian dengan pertimbangan bahwa daerah ini merupakan salah satu basis perikanan laut di daerah Banten. Informasi lokasi ini diketahui dari hasil wawancara dan diskusi dengan pihak Dinas Perikanan dan Kelautan Kabupaten Pandeglang. Unit analisis penelitian ini adalah masyarakat nelayan di suatu desa atau komunitas yang mengelola sumberdaya perikanan sebagai mata pencaharian utama. Sistem masyarakat di dalam penelitian ini juga dipahami sebagai sebuah hasil kumpulan beraneka macam tindakan-tindakan sosial budaya yang saling terkait satu dengan lainnya.

\section{Jenis dan Sumber Data}

Sifat data yang digunakan berupa data kualitatif. Jenis data yang digunakan dalam penelitian ini adalah berupa data primer dan sekunder. Data primer didapatkan dari para informan yang terdiri dari petugas Dinas Perikanan dan Kelautan Kabupaten Pandeglang, pegawai kantor cabang Dinas Perikanan di Kecamatan Labuan dan nelayan. Data primer yang dikumpulkan terkait dengan permasalahan persepsi hak kepemilikan, konservasi dan pengetahuan lokal masyarakat setempat. Data sekunder yang digunakan dalam penelitian ini adalah berupa laporan-laporan dinas kelautan dan perikanan dan penelitian-penelitian yang terkait.

\section{Metode Pemilihan Informan dan Pengumpulan Data}

Pengumpulan data primer dilakukan melalui dua teknik, yaitu teknik indepth interview dan pengamatan. Indepth interview dilakukan menggunakan cara dan suasana yang berbeda bagi setiap informan disesuaikan dengan kondisi dan keterbatasan yang ada. Kondisi dan keterbatasan tersebut meliputi ketersediaan waktu, tempat dan alat bantu pengumpulan data. Informan adalah orang-orang yang dianggap banyak mengetahui dan terlibat langsung dalam permasalahan atau kasus yang ada di lokasi penelitian. Kemudian ditentukan informan-informan tersebut sebagai subjek penelitian bukan sebagai objek penelitian. Kondisi ini diperlukan untuk mendapatkan data yang benar-benar valid.

Pemilihan informan dilakukan dengan teknik snowballing sampling. Pemilihan informan selanjutnya ditentukan berdasarkan informasi dan rekomendasi dari informan sebelumnya. Teknik ini dilakukan karena tujuan yang ingin dicapai adalah mendapatkan tokohtokoh kunci. Jumlah informan kunci yang diambil informasinya sebanyak empat orang, yaitu tokoh nelayan payang, pancing dan bagan. Informan tambahan sebanyak delapan orang sebagai upaya memverifikasi data yang didapat dari informan kunci.

\section{Metode Analisis Data}

Analisis data dilakukan secara deskriptif dan diinterpretasikan menggunakan metode logik. Metode logik adalah cara menalar dimana data diamati dan dipilah-pilah, buktinya dicari dan dipertimbangkan, dianalisis dan kemudian kesimpulan diambil (Nazir, 1988). Interpretasi data dilakukan dengan menggunakan pendekatan dan teori rational choice dan teori prisoner dilemma. Teori rational choice mengasumsikan manusia berperilaku rasional dan mendasarkan tindakan mereka atas cara-cara yang mereka anggap paling efektif dalam mencapai tujuannya. Tindakan manusia juga ditujukan pada pencapaian utilitas maksimum (Wallace \& Wolf, 1999). Teori prisoner dilemma merupakan pendekatan yang digunakan untuk menjelaskan pilihan strategi yang dianggap paling rasional dari masing-masing pelaku ketika dihadapkan pada pelaku lainnya. Pilihan strategi tersebut dibuat dengan meminimalkan korbanan yang mungkin akan dikeluarkan dari setiap tindakan yang dilakukan (Fletcher \& Zwick, 2000). Analisis menggunakan prinsip prisoner dilemma mensyaratkan setiap individu yang melakukan pilihan rasional dengan terikat pada "prinsip keterasingan dan ketimpangan informasi" dari individu lainnya. Kedua pendekatan teori tersebut digunakan untuk menjelaskan persepsi hak kepemilikan yang ada di dalam kehidupan masyarakat. Selain itu, teori rational choice digunakan juga untuk mengkaji halhal yang terkait dengan dasar pengambilan keputusan masyarakat dalam bertindak. Hasil analisis tersebut kemudian digunakan sebagai bahan menentukan model pengelolaan sumberdaya perikanan yang sebenarnya dipraktekkan masyarakat tersebut dengan menggunakan teori prisoner's dilemma.

Proses analisis data mengikuti framework analisis seperti terlihat pada gambar 1 . Proses analisis data meliputi kegiatan mengidentifikasi faktor-faktor 


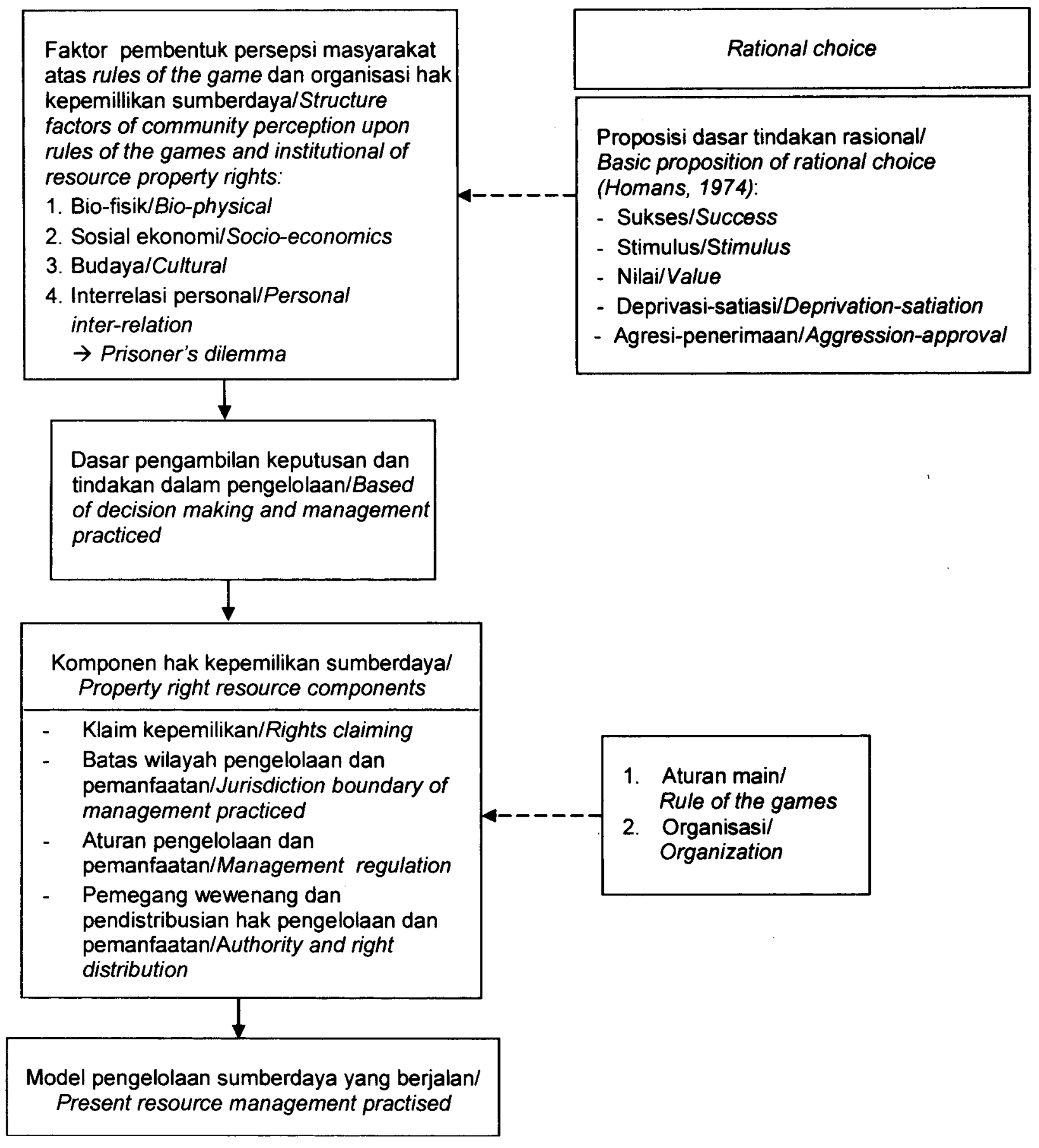

Gambar 1. Skema analisis data persepsi kepemilikan terhadap pengelolaan sumberdaya perikanan di Desa Teluk Pandeglang, Banten, 2004.

Figure 1. Data analysis flow chart of property right perception on fisheries resources management at the Teluk Village, Pandeglang, Banten, 2004.

pembentuk persepsi masyarakat atas rules of the games dan organisasi atas hak kepemilikan sumberdaya yang ada di lokasi penelitian. Analisis tersebut dilakukan dengan tujuan mendapatkan gambaran tentang hal-hal yang mendasari seseorang dalam bertindak. Persepsi masyarakat terkait dengan 
faktor-faktor yang membentuknya dianalisis dengan menggunakan pendekatan rational choice. Perspektif ini melihat pola-pola tindakan yang didasarkan atas pemenuhan kepentingan pelaku dalam jangka pendek. Selanjutnya, interpretasi data dilakukan dengan menggunakan teori prisoner's dilemma. Interpretasi data ini menggunakan asumsi pilihan konservasi dan atau eksploitasi yang menjadi dasar pengambilan keputusan dalam tindakan pengelolaan dan pemanfaatan sumberdaya, sehingga akan terlihat pilihan apa yang dianggap rasional, serta apa yang menjadi dasar bagi masyarakat terkait dengan tindakan yang mereka lakukan. Hal ini terkait dengan faktor pembentuk atas persepsi masyarakat terkait dengan hubungan interpersonal antara satu pelaku usaha dengan pelaku lainnya.

\section{HASIL DAN BAHASAN}

\section{Gambaran Umum Lokasi Riset}

Secara geografis, Desa Teluk, Kecamatan Labuan memiliki daerah pantai yang relatif sempit yang berhadapan langsung dengan Selat Sunda dan Samudera Hindia. Masyarakat di daerah ini memiliki mata pencaharian utama sebagai nelayan yang tersebar di sepanjang garis pantai. Masyarakat tersebut jika dilihat dari asal suku, secara garis besar dapat dibagi menjadi Suku Sunda, dan Bugis yang berasal dari daerah Banten, Cirebon, dan Sulawesi. Perilaku masing-masing suku dalam tindakan pemanfaatan sumberdaya perikanan berbeda-beda yang merupakan pengaruh dari nilai-nilai budaya masing-masing. Masyarakat yang berasal dari Suku Bugis banyak menggunakan bagan tancap dan atau bagan apung. Alat tangkap payang dan pancing banyak digunakan oleh masyarakat yang berasal dari Sunda, sedangkan alat tangkap arad dan purse-seine banyak digunakan oleh masyarakat yang berasal dari Cirebon. Kegiatan penangkapan umumnya bersifat harian (one day fishing) dengan jarak lokasi sekitar 4-5 mil laut dari pantai. Musim penangkapan umumnya dilakukan pada bulan-bulan April hingga Desember dan tiga bulan sisanya dianggap musim paceklik.

\section{Analisis Persepsi Masyarakat dalam Pengelolaan Sumberdaya Perikanan}

Analisis persepsi masyarakat mencakup faktorfaktor yang mempengaruhi pembentukan rules of the games dan organisasi dalam hak kepemilikan sumberdaya yang dilakukan oleh pelaku usaha perikanan tangkap. Persepsi atas faktor-faktor tersebut akan berpengaruh dalam tindakan yang diambil oleh pelaku usaha. Analisis terkait faktor- faktor ini melihat kondisi bio-fisik (bio-physical), sosial ekonomi (socio-economics), budaya (cultural) dan interrelasi personal (personal inter-relation). Analisis ini dimulai dengan beranjak dari pemahaman tentang adanya perilaku pemenuhan kepentingan sendiri dalam jangka pendek (short-term self interest) masyarakat yang cenderung menyebabkan pengelolaan sumberdaya perikanan yang bersifat open access, maka terdapat beberapa proposisi dasar tentang perilaku "rasional" masyarakat berdasarkan teori rational choice. Proposisi tersebut adalah: (1) proposisi sukses-the success proposition; (2) proposisi stimulus-the stimulus proposition; (3) proposisi nilai-the value proposition;(4) proposisi "deprivasi-satiasi"-the deprivation-satiation proposition; darl (5) proposisi agresi-penerimaan-the aggressionapproval proposition (Homans, 1974 dalam Wallace \& Wolf, 1999). Proposisi-proposisi tersebut dapat dijelaskan sebagai berikut :

Homans (1974) dalam Wallace \& Wolf (1999) menjelaskan bahwa proposisi sukses, stimulus dan nilai dapat diartikan sebagai tiga prinsip dasar perilaku rasional manusia. Argumentasi yang dikemukakan adalah bahwa setiap orang memiliki kecenderungan melakukan tindakan berulang yang memiliki suatu penghargaan tertentu. Manusia juga akan cenderung selalu merespon setiap stimulus yang berasosiasi terhadap suatu penghargaan. Manusia juga bertindak berdasarkan pada setiap nilai-nilai yang mereka harapkan. Proposisi deprivasi-satiasi sangat terkait dengan prinsip penurunan kepuasan marjinal. Proposisi ini menyebutkan bahwa setiap manusia hanya akan melakukan tindakan jika nilainya lebih besar dibandingkan usaha yang dikeluarkannya. Proposisi agresi-penerimaan sangat terkait dengan perbedaan harapan dan kenyataan yang ingin dicapai. Proposisi ini menyebutkan bahwa setiap tindakan manusia akan selalu berdasarkan atas pertimbangan tindakan (kenyataan) mana yang lebih tepat dalam mencapai harapan (Homans, 1974 dalam Wallace \& Wolf, 1999).

\section{Persepsi Tentang Kondisi Bio-Fisik}

Masyarakat nelayan dalam kesehariannya menghadapi sumberdaya yang bersifat commons lebih memahami kebutuhan mereka dibandingkan pihak lain yang tidak berhadapan langsung dengan sumberdaya tersebut. Hal ini disebabkan karena respon dari masing-masing masyarakat di tempat lain akan berbeda, terkait penipisan dan kondisi sumberdaya. Persepsi mendahulukan kepentingan jangka pendek sendiri terjadi dalam kegiatan penangkapan di sebagian besar wilayah. Hasil wawancara juga menyebutkan bahwa desakan ekonomi menuntut masyarakat untuk melakukan segala hal demi 
memenuhi kebutuhan hidup. Anggapan "ikan tidak akan habis" juga mendorong perilaku "short-term self interest"'

Masyarakat dengan tingkat ketergantungan yang sangat tinggi atas sumberdaya dan memiliki teknologi terbatas akan lebih cepat dan aktif merespon penipisan sumberdaya. Penipisan sumberdaya dapat dianggap sebagai sebuah ancaman bagi kelangsungan hidup dan usahanya. Berbeda halnya dengan masyarakat yang tidak terlalu bergantung atas sumberdaya yang sama atau memiliki tingkat teknologi yang lebih tinggi. Masyarakat dapat dengan mudah berpindah ke sumberdaya lain. Sehingga maraknya kasus anarkis yang melibatkan nelayan-nelayan tradisional terhadap armada dan alat tangkap yang dianggap "merugikan" dan "mengancam" kelangsungan usaha dianggap oleh mereka tak lebih dari usaha pembelaan diri terhadap kelangsungan hidup.

Secara umum, semua informan menyebutkan bahwa menurut persepsi dan pengalaman mereka bahwa ikan yang berada di perairan tempat mereka beroperasi telah jauh berkurang. Indikasi yang mereka kemukakan atas kondisi ini adalah beberapa waktu yang lalu (sekitar tahun 1980-an) kegiatan penangkapan banyak dilakukan tidak jauh dari pantai dengan hasil yang sudah cukup banyak. Kondisi sekarang ini, terutama setelah semakin banyaknya nelayan dari luar yang datang maka kegiatan penangkapan harus dilakukan lebih jauh, lebih lama dengan hasil yang tidak sebaik seperti dahulu. Namun demikian, seperti telah disebutkan sebelumnya bahwa seluruh informan menolak anggapan bahwa suatu saat ikan akan habis di lautan. Indikasi yang mereka kemukakan adalah bahwa kenyataan berpuluh-puluh tahun ikan ditangkap tetapi tidak pernah habis hingga sekarang.

Kondisi open access dalam prakteknya juga menyebabkan tidak adanya pihak-pihak yang bertanggung jawab dalam upaya konservasi. Demikian juga halnya yang terjadi pada masyarakat di Desa Teluk, mereka menganggap upaya konservasi hanya dianggap sebagai tindakan yang tidak ekonomis dibandingkan tindakan eksploitasi. Hal ini berdasarkan penuturan seluruh informan yang ditemui di lokasi penelitian. Lebih lanjut disebutkan oleh seluruh informan bahwa masyarakat dalam kesehariannya menganggap wilayah konservasi terbagi menjadi dua, yaitu wilayah konservasi pemerintah dan tradisional. Wilayah konservasi pemerintah berlaku di sekitar Taman Nasioanal Ujung Kulon dan berlaku hukum positif. Keberadaan upaya konservasi yang dikenalkan secara formal oleh institusi pemerintah belum dikenal luas. Pada kenyataannya wilayah konservasi pemerintah tidak luput dari kegiatan eksploitasi secara tidak ramah lingkungan. Berdasarkan informasi dari informan didapatkan fakta bahwa secara diam-diam atau bekerjasama dengan oknum setempat, masyarakat "bisa" menangkap ikan di daerah tersebut. Wilayah konservasi dan kegiatan konservasi bukan "tanggung jawab" mereka

\section{Persepsi Tentang Kondisi Sosial Ekonomi}

Deval (1985) dalam Kinseng (2003) menyebutkan bahwa setiap makhluk dan kesatuannya di dalam lingkungan hidup merupakan kesatuan utuh yang mempunyai nilai intrinsik (hakiki) sama. Pengertian lainnya adalah bahwa manusia mempunyai nilai atau kedudukan yang sama dengan semua makhluk lainnya. Seperti telah disebutkan sebelumnya, tindakan manusia dalam menghadapi sumberdaya "milik bersama" adalah lebih mengarah kepada sifat "pemenuhan kepentingan diri sendiri dalam jangka pendek" (short-term self interest).

Sebagai contoh kasus di masyarakat Teluk, berdasarkan informasi seluruh informan, umumnya menyatakan bahwa penyebab utama berkurangnya ikan hasil tangkapan adalah adanya "pencurian" ikan oleh nelayan pendatang. Mereka menyebutkan "pencurian" ikan tersebut menggunakan alat tangkap yang lebih besar dan aktif seperti arad atau mini trawl. Contoh nelayan pendatang yang dipersoalkan masyarakat adalah nelayan Sibolga. Menurut penuturan seluruh informan, terhadap perilaku nelayan Sibolga ini masyarakat melakukan reaksi. Reaksi tersebut berupa tantangan keras dalam bentuk penangkapan terhadap kapal pendatang. Kapalkapal pendatang tersebut bahkan ada yang dibakar, alat tangkapnya dirusak atau ditenggelamkan sehingga konflik sosial tidak terhindarkan.

Hal yang sangat menarik adalah pandangan dari seluruh informan yang diwawancarai menyebutkan bahwa penilaian kasus "pencurian" tidak didasarkan atas penilaian bahwa masyarakat merupakan pemilik sumberdaya tersebut. Sewajarnya jika merujuk kata "pencurian" maka mengandung makna ada sesuatu hal yang diambil dari hak milik seseorang. Alasan yang dikemukakan oleh seluruh informan adalah "pencurian" sebagai hal yang akan merugikan atau bahkan mengancam kelangsungan usaha. Hal lainnya yang menjadi alasan adalah rasa tidak puas diri melihat pihak lain memiliki alat tangkap yang dapat menghasilkan jumlah tangkapan yang relatif lebih banyak. Sehingga tindakan penentangan, pengusiran, pengrusakan oleh masyarakat tetap dipandang sebagai tindakan yang dilakukan berdasarkan pertimbangan yang rasional 
karena jika didiamkan maka ikan akan semakin berkurang. Pandangan ini sesuai dengan konsep pilihan rasional yang menyebutkan bahwa seseorang akan bertindak sesuai dengan pilihan yang dianggap paling "rasional" dan terlebih dahulu akan menguntungkannya dibandingkan pilihan lainnya (self interest).

\section{Persepsi Tentang Kondisi Budaya}

Kondisi pilihan rasional juga terlihat berdasarkan penggalian informasi terkait dengan konservasi. Hasil penggalian informasi mendapatkan bahwa sebagian besar informan ( 7 orang) menganggap bahwa masyarakat secara tradisional masih memiliki nilainilai pengetahuan lokal dalam pengelolaan sumberdaya perikanan. Pengetahuan lokal tersebut hanya terbatas pada wilayah "konservasi" pada beberapa karang yang dianggap memiliki "kekuatan gaib". Wilayah "kekuatan gaib" ini relatif tidak terganggu keberadaannya dibandingkan dengan wilayah konservasi milik pemerintah. Seperti telah disebutkan sebelumnya, tindakan menghindari daerah karang tersebut bukan karena karang itu dianggap mempunyai nilai luhur yang sama dengan manusia sehingga harus dihormati. Menurut informan-informan tersebut masyarakat enggan untuk mengganggu wilayah tersebut karena takut "kekuatan gaib" yang ada marah sehingga menimbulkan bencana bagi pelakunya. Tindakan ini merupakan suatu tindakan yang "rasional" dan self-interest (Ridley \& Low, 1993).

Wilayah konservasi tradisional yang dianggap oleh masyarakat setempat hanya berupa wilayah sempit tempat karang-karang berada dan berlaku hukum normatif. Hukum normatif yang berlangsung hanya berupa pemahaman mendapatkan celaka (pamali) jika melanggarnya. Berbeda halnya dengan wilayah konservasi pemerintah, wilayah konservasi tradisional tidak mengharuskan masyarakat untuk menjaganya. Hal ini karena persepsi masyarakat yang menganggap wilayah tersebut sudah ada "kekuatan gaib" yang menjaganya. Persepsi ini muncul dan diturunkan dari generasi ke generasi melalui tokoh-tokoh masyarakat. Jika dilihat dari hasil wawancara dengan para informan, mereka beranggapan sangat rasional untuk menjauhi wilayah karang tersebut dibandingkan harus mengalami kerusakan perahu akibat karang atau "kekuatan gaib".

\section{Persepsi tentang Kondisi Hubungan Inter- personal}

Teori rational choice mengasumsikan manusia berperilaku rasional dan mendasarkan tindakan mereka atas cara-cara yang mereka anggap paling efektif dalam mencapai tujuannya (Wallace \& Wolf,
1999). Selanjutnya disebutkan dalam dunia yang penuh kelangkaan sumberdaya, hal ini berarti bahwa manusia terus menimbang-nimbang untuk memilih berbagai cara alternatif dan hasil akhirnya. Tindakan manusia sangatlah dipengaruhi oleh persepsi yang tercipta dalam kehidupannya, demikian juga halnya dengan eksploitasi dan konservasi.

Kemudian untuk melihat perilaku masyarakat di Desa Teluk dalam usaha memenuhi kepentingan sendiri dalam jangka pendek (short-term self interest) selanjutnya digunakan teori prisoner's dilemma. Analisis ini berdasarkan hasil penggalian informasi terhadap fakta-fakta yang ada di masyarakat seperti yang telah dijabarkan sebelumnya. Perilaku masyarakat di Desa Teluk dalam praktek pemanfaatan dan pengelolaan sumberdaya perikanan dapat dijelaskan sebagai berikut: nelayan A dan B merupakan pelaku usaha yang memanfaatkan sumberdaya yang sama pada wilayah yang sama. Pengkategorian nelayan A dan B dapat diartikan sebagai hubungan antara individu dengan individu ataupun kelompok dengan kelompok. Analisis ini menitik beratkan pada konsep hubungan antara satu pelaku dengan pelaku lainnya.

Nelayan A dan B dihadapkan pada satu pilihan apakah harus mengeksploitasi atau mengkonservasi sumberdaya perikanan. Keduanya juga dihadapkan pada kondisi ekonomi yang mengharuskan masingmasing memilih tindakan yang mereka anggap paling rasional. Eksploitasi dan konservasi sama-sama memiliki peluang yang sama dalam mempengaruhi pendapatan yang akan diperoleh. Baik nelayan A dan B menyadari bahwa konservasi akan menambah pengeluaran melalui biaya produksi yang bertambah bisa mencapai lebih dari dua kali lipat dari biasanya.

Jika kedua nelayan melakukan eksploitasi (strategi P) maka pengeluaran berlebih tidak akan terjadi, walaupun disadari sumberdaya semakin lama semakin menipis. Penipisan ini tentu akan berujung pada sedikit berkurangnya pendapatan. Jika salah satu nelayan (strategi $Q$ dan R) melakukan upaya konservasi, yang berarti pengeluaran berlebih dilakukan, akan menguntungkan nelayan yang hanya mengeksploitasi saja. Pilihan konservasi sangat beresiko bagi mereka karena tidak ada jaminan bahwa pihak lain juga akan melakukan konservasi. Namun, jika kedua nelayan (strategi S) melakukan konservasi akan menambah pengeluaran berlebih dan pendapatan berkurang karena terpakai untuk biaya konservasi. Maka secara "rasional", masingmasing nelayan memilih strategi $P$ dalam kegiatan penangkapan kesehariannya. Strategi $P$ bagi masing-masing nelayan dapat disebut sebagai strategi dominan. Pemilihan strategi $P$ sebagai 
Tabel 1. Matriks pola persepsi jangka pendek masyarakat terkait dengan eksploitasi dan konservasi sumberdaya perikanan Desa Teluk, Pandeglang, Banten, 2004

Table 1. Short-term of community perseption pattern matrix in relation to fisheries resource exploitation and conservation of the Teluk Village, Pandeglang, Banten, 2004

\begin{tabular}{|c|c|c|c|}
\hline \multirow{4}{*}{ 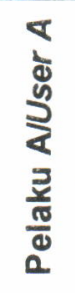 } & & \multicolumn{2}{|c|}{ Pelaku B/User B } \\
\hline & & Eksploitasi/Exp/oitation & Konse rvasi/Conservation \\
\hline & Eksploitasi/Exploitation & $\mathrm{P}(<1,<<C)$ & $Q(>1,>>C)$ \\
\hline & Konservasi/Conservation & $\mathrm{R}(>>\mathrm{C},>1)$ & $S(<1,>C)$ \\
\hline & $\begin{array}{l}I=\text { pendapa } \\
C=\text { pengelu } \\
P, Q, R, S=p\end{array}$ & $\begin{array}{l}\text { an/income } \\
\text { aran/expenditure } \\
\text { lihan strategi/strategy }\end{array}$ & \\
\hline
\end{tabular}

strategi bersama dikatakan sebagai keseimbangan strategi dominan.

Berdasarkan analisis prisoner's dilemma, dapat dilinat bahwa pilihan strategi dominan masing-masing pelaku dianggap merupakan pilihan paling "rasional". Secara kumulatif, seluruh pelaku dihadapi pada pilihan "rasional" yang sama. Akumulasi pilihan tersebut dalam keseharian menjadi sebuah tindakan kolektif yang dilakukan dalam memanfaatkan sumberdaya perikanan. Tindakan kolektif ini berujung kepada penipisan sumberdaya perikanan dan akhirnya berdampak pada penurunan kesejahteraan seluruh pelaku usaha. Secara sederhana pola hubungan persepsi eksploitasi dan konservasi dalam masyarakat Teluk dapat dilihat pada Tabel 1. Berdasarkan Tabel 1. dapat dilihat pola persepsi masyarakat Teluk terkait dengan pemanfaatan sumberdaya perikanan.

Pada kondisi yang berbeda dapat dilihat bahwa terdapat peluang terjadinya pilihan strategi yang berbeda. Kondisi prisoner's dilemma sangat terkait dengan adanya prinsip keterasingan informasi antara satu pelaku dengan pelaku lainnya. Keterasingan informasi dapat terjadi ketika masingmasing individu tidak saling bertukar informasi secara sempurna atau masing-masing pelaku tidak terikat dalam sebuah ikatan kohesi sosial yang tinggi. Hal ini menyebabkan walaupun pertukaran informasi dapat terjadi secara sempurna, namun tidak dapat berjalan karena masing-masing pelaku tidak saling mempercayai informasi yang diterima.

Kondisi pilihan strategi yang diambil terkait dengan prinsip eksternalitas, yaitu kegiatan yang dilakukan oleh satu pihak akan berpengaruh terhadap kegiatan yang dilakukan oleh pihak lainnya. Persepsi bahwa tidak adanya jaminan bagi pihak lain akan melakukan hal yang sama terkait dengan konservasi membuat enggannya seseorang untuk melakukan konservasi. Jika kondisi masyarakat berada dalam satu ikatan kohesi sosial yang tinggi, dapat terjadi dalam bentuk keberadaan kelembagaan sosial yang sangat berperan, maka kondisi keterasingan informasi atau ketidakpercayaan sangat kecil kemungkinannya terjadi.

Oleh karenanya, masing-masing individu akan saling bertukar informasi dan dapat saling menjamin bahwa kegiatan konservasi yang memang telah dirasakan perlu untuk dilakukan akan dilakukan secara bersama-sama. Pihak-pihak free-rider akan berkurang jumlahnya, karena setiap individu akan menjadi pengawas dan beban moral akan menjadi sebuah sanksi sosial yang efektif. Masing-masing individu akan saling memahami untuk mengurangi sebagian kecil pendapatannya dengan berpartisipasi dalam kegiatan konservasi secara bersama-sama. Pada akhirnya kondisi yang terjadi adalah masingmasing pihak akan menyadari bahwa biaya yang dikeluarkan untuk konservasi tidaklah terlalu besar karena ditanggung oleh banyak pihak. Maka pilihan strategi rasional lain yang dipilih secara bersama oleh masing-masing pelaku adalah pilihan strategi S.

Terkait dengan hasil analisis rational choice dan prisoner's dilemma maka dapat disimpulkan bahwa persepsi masyarakat berpengaruh dalam membentuk pola tindakan pengelolaan. Demikian juga halnya dengan penelitian yang dilakukan oleh Nasution et al. (2004) menyebutkan bahwa persepsi terhadap hak kepemilikan berperanan dalam membentuk pola pengelolaan dan pemanfaatan atas sumberdaya. Pola tindakan tersebut berdasarkan hasil analisis didasari atas prinsip short-term self 
interest dan menghasilkan strategi yang dianggap paling rasional dalam memilih eksploitasi atau konservasi sumberdaya perikanan. Namun terdapat beberapa hal yang dapat digali dari kearifan lokal dalam usaha konservasi dan pengelolaan sumberdaya perikanan.

\section{Komponen Hak Kepemilikan Sumberdaya}

Seperti telah dijelaskan sebelumnya, bahwa berdasarkan hasil analisis dan interpretasi data di atas, persepsi memiliki pengaruh terhadap tindakan yang akan diambil oleh seseorang. Demikian juga halnya terhadap faktor-faktor bio-fisik, sosial ekonomi, budaya dan relasi interpersonal yang berpengaruh terhadap tindakan seseorang terhadap hak kepemilikan sumberdaya. Berikut ini dilakukan identifikasi terkait dengan komponen-komponen hak kepemilikan sumberdaya yang ada di lokasi riset. Identifikasi yang dilakukan tetap mengacu kepada persepsi dan tindakan yang diambil oleh masyarakat. Identifikasi hak kepemilikan sumberdaya sangatlah penting untuk dilakukan, mengingat hak kepemilikan akan berpengaruh terhadap sifat akses dan pengelolaan sumberdaya tersebut.

Identifikasi komponen hak kepemilikan di daerah penelitian ini dilakukan berdasarkan konsep yang diajukan oleh Bromley (1991). Persepsi dan konsepsi terhadap sistem dan mekanisme pengelolaan dan pemanfaatan dalam penelitian ini lebih ditekankan kepada permasalahan hak kepemilikan sumberdaya (property rights). Bromley (1991) menyebutkan bahwa unsur-unsur atau komponen-komponen property rights dalam pengelolaan sumberdaya meliputi: (1) klaim kepemilikan; (2) batas wilayah pengelolaan dan pemanfaatan; (3) pemegang wewenang dan pendistribusian hak pengelolaan dan pemanfaatan; dan (4) aturan pengelolaan dan pemanfaatan (rules of the game). Lebih lanjut Bromley menekankan bahwa hak kepemilikan lebih mengarah kepada adanya mekanisme sosial yang memberikan wewenang, serta mengikat individu dalam suatu masyarakat atas kepemilikan wewenangnya. Pengelolaan sumberdaya juga dapat dipandang sebagai suatu kesatuan dari struktur hak dan kewajiban. Struktur hak dan kewajiban tersebut mewarnai pola hubungan antara seorang individu dengan lainnya atas sumberdaya yang sama. Hasil penelitian yang dilakukan di daerah ini telah mengidentifikasi unsur-unsur yang terdapat dalam konsep hak kepemilikan sebagai berikut:

\section{Klaim Kepemilikan}

Klaim kepemilikan sumberdaya di Desa Teluk dapat dilihat dari persepsi mereka atas sifat sumberdaya tersebut. Masyarakat nelayan menganggap laut adalah milik Allah semata dan semua orang memiliki hak untuk memanfaatkannya. Seluruh informan (12 orang) yang dimintai keterangan berpendapat bahwa penilaian tersebut sangat kental diwarnai oleh Agama Islam yang dianut. Mereka merujuk terhadap pendapat tentang konsep "kalifah di muka bumi" yang bersifat given dari Allah. Berdasarkan hal tersebut, maka keseluruhan informan menyebutkan semua orang merasa berhak untuk memanfaatkannya. Selain itu, sebagian besar informan (8 orang) juga menyebutkan persepsi lainnya terkait dengan kondisi sumberdaya perikanan. Hal tersebut terlihat dari anggapan bahwa "ikan tidak akan sampai habis di lautan, namun hanya akan berkurang".

Namun demikian, berdasarkan hasil observasi dan wawancara juga didapatkan fakta bahwa masyarakat secara perorangan secara terbatas melakukan klaim tidak langsung atas sumberdaya perikanan terutama dengan menggunakan jenis alat tangkap bagan (tancap maupun apung). Berdasarkan hasil wawancara didapat bahwa sebagian informan (4 orang) menganggap "klaim" ini sebenarnya muncul akibat sifat alat tangkap tersebut yang menetap pada satu lokasi dengan jangka waktu tertentu. Informan tersebut merupakan tokoh-tokoh nelayan yang menggunakan alat tangkap bagan dalam kesehariannya. Demikian juga halnya "klaim" tidak langsung juga terjadi pada nelayan yang menggunakan sejenis rumpon (dalam bahasa daerah setempat disebut tenda). Hal tersebut berdasarkan keterangan dari informan yang berjumlah 4 orang dan merupakan pihak-pihak yang menggunakan secara langsung jenis alat tangkap tersebut. Alat tangkap tersebut terbuat dari berbagai macam bahan, namun umumnya digunakan rangkaian batang bambu dan daun kelapa. Penggunaan rumpon ditujukan menarik ikan agar berkumpul di sekitar tempat tersebut. Pemiliknya menggunakan suatu penanda seperti bendera, pelampung atau lainnya pada bagan ataupun rumpon. Kepemilikan rumpon bersifat perorangan atau kelompok kecil. Klaim muncul pada saat rumpon tersebut dioperasionalkan.

\section{Batas Wilayah Pengelolaan dan Pemanfaatan}

Hasil penggalian informasi dan observasi di lapangan menunjukkan fakta bahwa masyarakat di daerah ini, secara komunitas, tidak memiliki batas wilayah pengelolaan dan pemanfaatan sumberdaya perikanan. Hal tersebut berdasarkan penuturan dari seluruh informan yang menyebutkan bahwa masyarakat di dalam kesehariannya tidak mengklaim suatu batas wilayah apapun di laut mereka. Salah satu alasan yang diajukan oleh seluruh informan (12 orang) terkait dengan tidak adanya batas wilayah 
karena anggapan mereka bahwa "ikan tidak bisa dilarang untuk berpindah tempat". Seluruh informan (12 orang) yang ditemui di lokasi penelitian juga beranggapan bahwa jika mereka menerapkan suatu batas wilayah tertentu dan melarang masyarakat daerah luar memanfaatkan sumberdaya perikanan, maka pada waktu yang bersamaan masyarakat daerah luar akan menerapkan hal yang sama. Masih berdasarkan penuturan keseluruhan informan, bahwa permasalahan muncul ketika sumberdaya perikanan tersebut pada satu waktu (musim) tertentu berada di daerah lain. Hal tersebut menyebabkan mereka tidak mungkin untuk melakukan pembatasan wilayah pemanfaatan karena mereka pun akan terus bergerak mencari ikan. Seluruh informan menyebutkan bahwa masyarakat telah mengetahui bahwa keberadaan suatu jenis sumberdaya perikanan (seperti kembung, layur dan bawal) mengikuti pola musim tertentu. Pengetahuan ini mereka dapatkan secara turuntemurun berdasarkan pengalaman-pengalaman pendahulu mereka.

Terkait dengan penggunaan sistem bagan dan rumpon, berdasarkan informasi dari seluruh informan di lapangan didapatkan kenyataan secara tidak tertulis dan telah menjadi kesepakatan umum, bahwa hanya pemiliknya yang dianggap berhak untuk memanfaatkan sumberdaya perikanan yang ada di daerah tempat alat tangkap tersebut beroperasi.
Namun demikian, menurut seluruh informan (12 orang) disebutkan bahwa "batas wilayah" kepemilikan tersebut bersifat sangat terbatas dan hanya berlaku selama alat tangkap tersebut masih operasional. Pemiliknya juga bebas mencari lokasi lain ketika dirasakan sumberdaya perikanan yang ada semakin berkurang atau alat tangkap tersebut telah rusak.

\section{Aturan Pengelolaan dan Pemanfaatan}

Masyarakat di Desa Teluk, berdasarkan penuturan seluruh informan, menyebutkan bahwa secara komunitas mereka tidak memiliki aturan pengelolaan dan pemanfaatan sumberdaya. Kegiatan penangkapan keseharian tidak memiliki pernbatasan terhadap orang-orang ataupun kelompok dalam memanfaatkan sumberdaya perikanan yang ada. Demikian juga halnya terhadap aturan penggunaan alat tangkap dan waktu penangkapan yang tidak terdapat di daerah ini. Dengan demikian, kegiatan pengelolaan dan pemanfaatan sumberdaya berlangsung secara open access. Hal ini disebabkan oleh masyarakat tidak mengenal adanya sistem hak kepemilikan atas sumberdaya perikanan (nonproperty right system). Hal ini terungkap dari hasil wawancara yang dilakukan terhadap seluruh informan (12 orang). Kondisi ini sesuai dengan kondisi yang disyaratkan oleh Bromley (1992), yaitu jika property right benar-benar tidak ada (non-property right sys-

Tabel 2. Keadaan komponen sistem hak kepemilikan di tingkatan masyarakat Desa Teluk, Pandeglang, Banten, 2004

Table 2. Summary of property right system component at the Teluk Village, Pandeglang, Banten Community Level, 2004

\begin{tabular}{llc}
\hline No & $\begin{array}{c}\text { Komponen dalam sistem hak kepemilikan/ } \\
\text { Property right system's component }\end{array}$ & $\begin{array}{c}\text { Ada/ Tidak adal } \\
\text { Exist } \\
\text { Absent }\end{array}$ \\
\hline 1 Klaim kepemilikan/Claim of property rights & $\mathrm{X}$ \\
2 & $\begin{array}{l}\text { Batas wilayah pengelolaan dan pemanfaatan/Teritorial } \\
\text { jurisdiction of exploitation and management }\end{array}$ \\
3 & $\begin{array}{l}\text { Aturan pengelolaan dan pemanfaatan/Exploitation and } \\
\text { management regulation }\end{array}$ \\
4 & $\mathrm{X}$ \\
& $\begin{array}{l}\text { Pemegang wewenang dan pendistribusian hak } \\
\text { mechanism of exploitation and mangement right } \\
\text { distibution }\end{array}$
\end{tabular}

Catatan/Remarks: Secara perseorangan dan dalam kondisi sangat terbatas sebenarnya melakukan klaim kepemilikan (terkait dengan pengoperasian alat tangkap bagan dan penggunaan rumpon)/There is property right-claiming at individual level eventhough in a very limited condition, only regarding to the bagan and rumpon activities 
tem) di suatu daerah maka yang terjadivadalah pemanfaatan dan pengelolaan sumberdaya perikanan bersifat open access. Pemanfé tan bersifat open access umumnya selalu diikuti dengan kondisi tidak adanya pihak-pihak yang bertanggungjawab terhadap pengelolaan sumberdaya perikanan.

\section{Pemegang Wewenang dan Pengaturan Hak Pengelolaan dan Pemanfaatan}

Hasil wawancara yang dilakukan terrhadap seluruh informan, menyebutkan bahwa mereka menganggap tidak adanya pemegang wewenang pengelolaan sumberdaya perikanan. Persepsi ini muncul karena mereka beranggapan bahwa "laut tidak ada yang memiliki secara perorangan". Berdasarkan hasil pengamatan didapatkan bahwa kebebasan dalam memanfaatkan sumberdaya perikanan bagi setiap orang membuat tidak adanya lembaga-lembaga dalam masyarakat yang berperan sebagai pengelola sumberdaya perikanan. Tidak adanya lembaga pemegang wewenang pengelolaan sumberdaya perikanan, pada gilirannya menyebabkan tidak adanya pendistribusian hak pengelolaan dan pemanfaatan kepada anggota masyarakat. Hal ini pun diakui oleh seluruh informan yang dimintai informasi terkait dengan ketidakberadaan lembagalembaga yang mengatur kewenangan dan pendistribusian hak pengelolaan dan pemanfaatan. Dengan demikian, prinsip non-property right system yang berujung pada pengelolaan secara open access mengandung pengertian bahwa tidak adanya pihak yang memiliki hak atas sumberdaya perikanan menyebabkan semua orang dapat mengaksesnya secara bebas. Secara ringkas pada Tabel 2 dapat dilihat kondisi keberadaan komponen sistem hak kepemilikan yang ada di masyarakat Desa Teluk.

Berdasarkan hal tersebut, maka dirasakan kebijakan pengelolaan sumberdaya perikanan sudah seharusnya tidak hanya bertitik berat pada peningkatan teknologi dan pelestarian nilai budaya semata. Semakin kuatnya arus materialisme, "rasionalitas" dan individualisme akan menyebabkan selalu ada kecenderungan untuk meninggalkan institusi lokal (Kinseng, 2003). Lebih lanjut Kinseng (2003) menyebutkan bahwa pengembangan institusi lokal tidak hanya cukup bersandar pada pendekatan nilai budaya saja (pelestarian), namun juga penekanan pada keuntungan ekonomi yang akan diperoleh akibat pengembangan tersebut. Penyertaan masyarakat dalam kebijakan pengelolaan sumberdaya perikanan juga perlu melihat dan mengakomodir "sifat dasar" manusia yang cenderung "mementingkan diri sendiri dan memaksimalkan utilitas". Maka dari itu, perlu adanya upaya untuk merubah persepsi masyarakat tentang konservasi yang merupakan sebuah tindakan rasional dan menguntungkan.

\section{KESIMPULAN DAN SARAN}

Persepsi masyarakat Desa Teluk terhadap hak kepemilikan sumberdaya sangat berpengaruh terhadap tindakan yang dilakukan dalam usaha pemanfaatan dan pengelolaan sumberdaya perikanan. Komponen hak kepemilikan yang terdapat di Desa Teluk terdiri dari klaim kepemilikan sumberdaya perikanan, batas wilayah, aturan pengelolaan dan pemegang wewenang dan pendistribusian hak pengelolaan. Klaim kepemilikan sangat erat kaitannya dengan persepsi masyarakat terhadap Tuhan sebagai pemilik sumberdaya perikanan dan semua orang berhak memanfaatkannya. Secara komunitas tidak ada klaim kepemilikan, batas wilayah, aturan pengelolaan berjalan secara open access dan tidak ada lembaga pemegang wewenang dan pendistribusian hak. Hasil analisis terhadap tindakan masyarakat berdasarkan persepsi mereka didapatkan tindakan yang diambil merupakan sebuah tindakan yang dianggap rasional bagi mereka. Berdasarkan matriks analisis prisoner's dilemma juga dapat diterangkan bahwa tindakan eksploitasi yang dilakukan oleh masyarakat dianggap lebih rasional oleh mereka dibandingkan dengan tindakan konservasi. Keseimbangan strategi dominan terjadi pada pilihan strategi eksploitasi-eksploitasi. Faktorfaktor pembentuk persepsi masyarakat adalah pemenuhan kepentingan diri sendiri dalam jangka pendek (short-term self interest) dan pilihan strategi yang dianggap rasional. Secara umum kondisi yang terjadi di masyarakat adalah berlangsungnya non-property right system yang berimplikasi terhadap pengelolaan sumberdaya perikanan secara open access

\section{DAFTAR PUSTAKA}

Babbie, E. 1991. The Practice of Social Research: Sixth Edition. Wadsworth Publishing Company. Belmont, California

Bakker, J.W.M. 1984. Filsafat Kebudayaan: Sebuah Pengantar. Penerbit Kanisius. Yogyakarta. 154 pp.

Benda-Beckman, F.V. 2001. Jaminan Sosial dan Manajemen Sumberdaya Alam: Refleksi Kompleksitas Normatif di Indonesia dalam BendaBeckman, FV, KV Benda-Beckman dan J Koning. 2001. Sumberdaya Alam dan Jaminan Sosial. Pustaka Pelajar. Yogyakarta.

Berry, D. 2003. Pokok-Pokok Pikiran Sosiologi. PT. Raja Grafindo Persada. Jakarta. 279 pp. 
Bromley, D.W. 1991. Environment and Economy: Property Rights and Public Policy. Basil Blackwell. Inc. Belmont, California

Bromley, D.W.1992. Making The Commons Work. (ed.). CA: Institute for Contemporary Studies. San Francisco Fletcher, J. A and Zwick, M. 2000. N-Player Prisoner's Dilemma in Multiple Groups:A Model of Multilevel Selection. Proceedings of the Artificial Life VII Workshops, Portland, Oregon.

Hardin, G. 1968. The tragedy of the commons. Science, 162:1243-1248.

Kinseng, R.A. 2003. Antroposentrisme dan SDA. Harian Umum Republika (Rabu, 20 Agustus 2003). Jakarta.

Koentjaraningrat. 1990. Pengantar IImu Antropologi. Rineka Cipta. Bandung. 391 pp.

Nasution, Z, Sastrawidjaja, Hartono, T.T, Mursidin, Priyatna, F.N, Pranadji, T, Aji, G.B, Koeshendrajana, S, Suherman, M. 2004. Riset Sosio-Antropologi dan Kelembagaan dalam Rangka Pemberdayaan
Masyarakat Kelautan dan Perikanan. Laporan Teknis. Bagian Proyek Pusat Riset Pengolahan Produk dan Sosial Ekonomi Kelautan dan Perikanan. BRKP. Departemen Kelautan dan Perikanan. Jakarta

Nazir, M. 1988. Metode Penelitian. Ghalia Indonesia. Jakarta.

Poerwanto, H. 2000. Kebudayaan dan Lingkungan dalam Perspektif Antropologi. Pustaka Pelajar. Yogyakarta. 304 pp.

Ridley, M and Low, B.S. 1993. Can Selfishness Save The Environnment?. The Atlantic Monthly.

Sitorus, M.T.F. 1998. Penelitian Kualitatif: Suatu Perkenalan. DOKIS. Bogor.

Susanto, A.S. 1984. Sosiologi Pembangunan. Penerbit Binacipta. Jakarta. 191 pp.

Wallace, R.A and Wolf, A. 1999. Contemporary Sociological Theory: Expanding the Classical Tradition (Fifth Edition). Prentice Hall. New Jersey. 